\title{
EVALUASI KESUBURAN TANAH SAWAH DI DESA RANOKOLO KECAMATAN MAUROLE KABUPATEN ENDE
}

\author{
Yeremias Dala $^{1}$, Charly Mutiara ${ }^{2}$ \\ Program Studi Agroteknologi, Fakultas Pertanian-Universitas Flores \\ Charlyinter1988@gmail.com
}

\begin{abstract}
Evaluation Of Rice Fields Fertility In Ranokolo Village, Maurole District, Ende District. Land that was managed by intensively will effect decreasing soil fertility. This condition happened in the rice fields in Ranokolo Village, Maurole District, Ende Regency. This study aims to determine the fertile of paddy soil, and the soil chemical criteria in the village have been carried out. This study uses a survey method, which is to determine the soil sample taken using the purposive sampling method. With this method obtained 13 research sites. Soil sampling in this study using soil samples that operated. And the replaced variables are $\mathrm{C}$-Organic, available $\mathrm{K}$, total $\mathrm{P}$, cation exchange capacity (CEC), and Base Saturation (KB). The results showed, the $\mathrm{C}$-Organic variable in Ranokolo Village, Maurole District, is classified as low, $\mathrm{K}$ as moderate, P-total as high, CEC is moderate, and Saturation of Bases as moderate. From the results of soil fertility analysis, the criteria for soil fertility in Ranokolo Village, Maurole District, Ende Regency is low with a C-Organic limiting factor.
\end{abstract}

Keywords : Criteria, Rice Field, Soil Fertility

\section{PENDAHULUAN}

Tanah merupakan suatu sistem yang dinamis, tersusun dari empat bahan utama yaitu mineral, bahan organik, air, dan udara. Bahan-bahan penyusun tanah tersebut masing-masing berbeda komposisinya untuk setiap jenis tanah, kadar air dan perlakuan terhadap tanah (Hanafia, 2010). Sebagai suatu sistem dinamis, tanah dapat berubah keadaannya dari waktu ke waktu, sesuai sifat-sifatnya yang meliputi sifat fisik, kimia dan biologi, serta keadaan lingkungan yang secara keseluruan menentukan kesuburan tanah.

Kesuburan tanah adalah potensi tanah untuk mempersiapkan unsur hara dalam jumlah yang cukup, tersedia dan seimbang. Hal ini meruapakan jaminan pertumbuhan dan produksi tanaman yang optimum (Anna dkk, 2010). Tanah yang diusahakan untuk bidang pertanian memiliki tingkat keseburan yang berbeda - beda, maka dari itu setiap tanah memerlukan adanya pengelolaan yang berbeda pula. Kondisi serupa dapat terjadi pada tanah sawah.

Kondisi tanah sawah cenderung mengalami penurunan kualitas serta tingkat kesuburan tanah. Hal ini dikarenakan intensifnya bubidaya padi, dilakukan dua bahkan tiga kali dalam satu tahun. Dalam setiap proses penanaman padi, maka dilakukan pula pengolahan tanah. Pengolahan tanah wajib dilakukan dengan tujuan meningkatkan sirkulasi air dan udara ke dalam tanah serta memudahkan 
pertumbuhan akar ke dalam tanah (Kramadibrata, 2000). Selain pengolahan tanah, pemupukan merupakan salah satu aktivitas Pertanian yang meningkat pada sawah-sawah yang intensif dibudidayakan.

Hal ini juga terjadi di Desa Ranokolo kecamatan Maurole kabupaten Ende. Pupuk anoragik menjadi solusi untuk memenuhi kebutuhan hara dalam tanah bahkan dosis yang diberikan melebihi anjuran demi meningkatkan produktifitas padi sawah. Pupuk tersebut diberikan pada varietas padi Ciheran, Ir, Membramo. Untuk memprtahankan produktifitas padi, para petani setempat menggunakan beberapa jenis pupuk anorganik dengan dosis Urea $250 \mathrm{~kg} / \mathrm{ha}$, Sp36 $150 \mathrm{~kg} / \mathrm{ha}$, Za $250 \mathrm{~kg} / \mathrm{ha}$, dan NPK $250 \mathrm{~kg} / \mathrm{ha}$.

Pemberian pupuk anorganik secara terus menerus serta aktivitas Pertanian yang intensif memberikan pengaruh pada kesuburan tanah (Susanto ,2002). Hal ini sejalan dengan hasil Kajian dari Sulakhudin dkk (2013). Hasil penelitian menunjukkan bahwa Sebagian besar tanah sawah di Kecamatan Sungai Kunyit memiliki Kapasitas Tukar Kation, Kejenuhan Basa, $\mathrm{P}$ total, $\mathrm{K}$ total dan $\mathrm{C}$-organik yang rendah. Status kesuburan tanah di sebagian lahan sawah di Kecamatan Sungai Kunyit ditentukan oleh nilai Kejenuhan Basa dan kandungan P total yang sangat rendah.

Dari hasil Kajian tersebut, dapat menjadi acuan bagaimana kesuburan tanah sawah yang ada di Desa Renokolo Kecamatan Maurole. Potensi sawah di tersebut cukup luas, namun pengembangan budidaya tanaman pangan masih belum optimal. Hal ini dapat terjadi karena pengelolaan tanah yang tepat dan efisen belum dapat diterapkan. Hal ini karena kurangnya data kesuburan tanah, sehingga menyulitkan para petani dalam penerapan jenis dan dosis pupuk yang tepat untuk mendukung produksi yang optimal. Data kesuburan tanah sawah dapat diperleh dengan melakukan evaluasi kesuburan tanah.

Evaluasi setatus kesuburan dilakukan untuk memiliki dan memantau kesuburan tanah. Penilaian evaluasi setatus kesuburan tanah dapat dilakukan melalui pendekatan uji tanah. Berdasarkan latar belakang diatas, perlu dilakukan penelitian dengan judul "Evaluasi Kesuburan Tanah Sawah di Desa Ranokolo Kecamatan Maurole Kabupaten Ende".

\section{METODOLOGI PENELITIAN}

\section{Tempat Dan Waktu}

Penelitian dilakukan pada areal pertanian yang terdapat pada dusun Ranokolo dan Dusun Wolondopo, Desa Ranokolo, Kecamatan Maurole, Kabupaten Ende serta Laboratorium Kimia Tanah Fakultas Pertanian Universitas Nusa Cendana. Penelitian direncankan dilakukan selama kurang lebih 3 bulan yaitu dari bulan Mei sampai Juli 2019.

\section{Bahan Dan Alat}

Bahan yang digunakan dalam penelitian ini adalah Sampel tanah dan bahan-bahan kimia yang di gunakan untuk analisis kimia tanah. Sedangkan peralatan yang digunakan dalam penelitian ini yaitu plastik Es, parang, pH meter, kamera, Spidol, Abney level, bor tanah, karet gelang, patok, spektrophotometer dan alat tulis.

\section{Rancangan penelitian}

Penelitian ini menggunakan metode survey, dimana untuk menentukan sampel tanah yang diambil, digunakan metode purposive sampling. Kriteria yang digunakan adalah varietas 
padi yang dibudidayakan di semua dusun di Desa Ranokolo.Varietas padi yang dibudidayakan dusun-dusun tersebut adalah viarietas Ciherang dan IR, sedangkan dusun yang ada di Desa Ranokolo adalah dusun Ranokolo dan Wolondopo. Sawah yang membudidayakan padi varietas Ciherang di Dusun Ranokolo sebanyak 3 lokasi dan yang membudidayakan padi varietas IR sebanyak 4 lokasi. Untuk dusun Wolondopo, sawah yang membudidayakan padi Varietas Ciherang sebanyak 3 lokasi, sedangkan yang membudidayakan padi varietas IR sebanyak 3 lokasi.

\section{Pelaksanaan penelitian}

\section{Penentuan titik sampel}

Penentuan titik sampel menggunakan metode purposive sampling. Dengan metode ini diperoleh 6 lokasi yang membudidayakan padi varietas ciherang di dusun Ranokolo dan Wolondopo serta 7 lokasi yang membudidayakan padi varietas IR di dusun Ranokolo dan Wolondopo.

\section{Pengambilan sampel tanah}

Sampel tanah yang diambil merupakan sampel tanah terganggu.Sampel tanah diambil sebanyak 5 titil sampel untuk setiap lokasi. Tanah yang diambil dari setiap titik sebanyak \pm 500 gram. Sampel tanah dari varietas yang sama dan dusun yang sama kemudian dikomposit, dan diambil tanah sebanyak $1 \mathrm{~kg}$ untuk dianalisis di laboratorium.

\section{Variabel Pengamatan}

Variabel yang diamati dalam penelitian ini adalah: $\mathrm{pH}$ tanah, COrganik Tanah, K-Tanah, P total, Kapasitas Tukar Kation dan Kejenuhan basa.

\section{Analisis Data}

Sampel tanah yang ada dianalisis di Laboratorium berdasarkan metode analisis kimia tanah untuk setiap variabel. Data hasil analisis laboratorium, dianalisis lebih lanjut untuk mengetahui karakteristik kimia dan status kesuburan tanahnya. Karakteristik kimia tanah ditentukan menggunakan kriteria penilaian status kimia tanah, sedangkan status kesuburan tanah ditentukan menggunakan petunjuk teknis evaluasi kesuburan tanah Pusat Penelitian Tanah (PPT, 1995).

\section{HASIL DAN PEMBAHASAN}

Sifat kimia tanah yang terdapat di lahan sawah di desa Ranokolo kecamatan Maurole kabupaten Ende yang dapat diamati yaitu $\mathrm{pH}$ Tanah, COrganik, K -Tersedia, P- total Kapasitas Tukar Kation (KTK), dan Kejenuhan Basa (KB). Hasil analisis sifat-sifat kimia tanah tersebut menunjukkan karakteristik dan kesuburan dari tanah sawah yang ada di Desa Ranokolo Kecamatan Maurole. Analisis sifat kimia tanah ini diambil dari 13 lokasi yang ada di Desa Ranokolo Kecamatan Maurole. Hasil analisis disajikan pada tabel 4.1 di bawah ini.

Tabel 4.1.Hasil Analisis Sifat Kimia Tanah

\begin{tabular}{lccccccc}
\hline No & $\begin{array}{c}\text { Kode } \\
\text { sampel }\end{array}$ & C-Organik & $\begin{array}{c}\mathbf{K} \\
\text { Tersedia } \\
(\mathbf{p p m})\end{array}$ & $\begin{array}{c}\mathbf{P} \\
\text { Total(mg/100 } \\
\mathbf{g})\end{array}$ & $\begin{array}{c}\text { KTK } \\
(\mathbf{m l} / \mathbf{1 0 0 g})\end{array}$ & $\begin{array}{c}\text { KB } \\
(\boldsymbol{\%})\end{array}$ & $\mathbf{p H}$ \\
\hline 1. & $\mathrm{D} 1 \mathrm{C} 1$ & $1,98 \mathrm{R}$ & $40,85 \mathrm{~S}$ & $120,53 \mathrm{~T}$ & $39,13 \mathrm{~S}$ & $73,60 \mathrm{~T}$ & $6,5 \mathrm{Am}$ \\
2. & $\mathrm{D} 2 \mathrm{C} 1$ & $1,57 \mathrm{R}$ & $31,90 \mathrm{~S}$ & $95,69 \mathrm{~T}$ & $37,44 \mathrm{~S}$ & $80,78 \mathrm{~T}$ & $6,0 \mathrm{Am}$ \\
3. & $\mathrm{D} 1 \mathrm{I} 1$ & $2,08 \mathrm{~S}$ & $45,24 \mathrm{~S}$ & $131,15 \mathrm{~T}$ & $38,45 \mathrm{~S}$ & $75,71 \mathrm{~T}$ & $5,6 \mathrm{Am}$ \\
4. & $\mathrm{D} 2 \mathrm{I} 1$ & $1,55 \mathrm{R}$ & $30,94 \mathrm{~S}$ & $90,81 \mathrm{~T}$ & $36,96 \mathrm{~S}$ & $78,87 \mathrm{~T}$ & $6,5 \mathrm{Am}$ \\
\hline
\end{tabular}




\author{
Keterangan: \\ D1C1: Dusun Ranokolo Varietas Ciherang \\ D2C1: Dusun Wolondopo Varietas IR \\ D1I1:Dusun Ranokolo Varietas Ciherang \\ D2I1:Dusun Wolondopo Varietas IR \\ $\mathrm{R}$ : Rendah \\ $\mathrm{S} \quad$ : Sedang \\ $\mathrm{T} \quad$ : Tinggi \\ AM : Agak Masam
}

\section{Tingkat Keasaman (pH Tanah)}

Hasil analisis ph tanah dari sampel-sampel tanah yang di ambil di lahan padi sawah diDesa Ranokolo dapat di sajikan pada tabel 4.1.1.

Tabel 4.1.1 Nilai pH tanah Sawah di Desa Ranokolo Kecamatan Maurole

\begin{tabular}{lccc}
\hline No & Kode sampel & $\mathbf{p H}$ & Kategori \\
\hline 1. & D1C1 & 6,5 & Agak masam \\
2. & D2C1 & 6,0 & Agak masam \\
3. & D1I1 & 5,6 & Agak masam \\
4. & D2I1 & 6,5 & Agak masam \\
\hline
\end{tabular}

Dari Hasil analisis $\mathrm{pH}$ tanah yang telah dilakukakan, diketahui bahwa keadaan tanah pada sawah di Desa Ranokolo tergolong Agak masam yang berada pada kisaran pH 5,6-6,5. Kondisi $\mathrm{pH}$ ini dapat menyebabkan pertumbuhan tanaman kurang optimal. Kondisi $\mathrm{pH}$ tanah yang agak masam pada lahan padi sawah diduga disebabkan oleh karena tercucinya basa-basa ke lapisan bawah oleh air hujan. Menurut Kartasapoetra et al.(1989), dalam Susilawati (2008), pH tanah yang rendah akan menyebabkan ketersediaan hara dan bahan organik menurun.
Ketersediaan hara yang menurun terkait dengan unsure hara makro yang ada di dalam tanah. Menurut Hanafiah (2010), unsure hara makro tersedia pada kisaran $\mathrm{pH}$ netral hingga agak basa. Atau dapat disimpulkan bahwa, pada kondisi di bawah netral, unsure hara makro menjadi kurang tersedia bagi tanaman.

\section{C-Organik Tanah}

Berdasarkan hasil analisis yang telah dilakukan, maka didapatkan hasil C-Organik tanah pada setiap sawah yang disajikan pada tabel 4.1.2 di bawah ini.

Tabel 4.1.2 Analisis sifat kimia tanah C-organik di Desa Ranokolo Kecamatan Maurole

\begin{tabular}{cccl}
\hline No & $\begin{array}{c}\text { Kode } \\
\text { sampel }\end{array}$ & C-Organik & Kriteria \\
\hline 1. & D1C1 & 1,98 & Rendah \\
2. & D2C1 & 1,57 & Rendah \\
3. & D1I1 & 2,08 & Sedang \\
4. & D2I1 & 1,55 & Rendah \\
\hline
\end{tabular}

Berdasarkan hasil analisis kimia tanah yang telah dilakukan, diketahui bahwa kandungan C-organik tanah sawah di Desa Ranokolo berada pada kondisi rendah. Kondisi ini dapat terjadi karena banyak kandungan bahan organik yang hilang akibat aliran permukaan. Aliran permukaan yang tinggi akan 
berkorelasi positif dengan tingginya bahan organik yang hilang. Aliran permukaan yang tinggi diakibatkan karena zona ini berada pada kondisiyang miring. Kondisi tanah yang miring akan mempercepat aliran permukaan di atasnya, sehingga menghilangkan banyak bahan organik (Hanafiah, 2010).

Kandungan bahan Organik tanah berperan sebagai kunci utama dalam mengendalikan kualitas tanah baik secara fisik,kimia, maupun biologi. Bahan organik mampu memperbaiki sifat fisik tanah seperi menurun berat volume tanah, meningkatkan permeabilitas, menggemburkan tanah, memperbaiki aerasi tanah, meningkatkan stabilitas agregat, meningkatkan kemampuan tanah memegang air,menjaga kelembaban dan suhu tanah, mengurangi energi kinetik langsung air hujan, mengurangi aliran permukaan dan erosi tanah (Rahayu, 2008).

\section{K- Tersedia}

Kandungan $\mathrm{K}$ tersedia di dalam tanah sawah di Desa Ranokolo Kecamatan Maurole telah dianalisis. Hasil analisis tersebut disajikan dalam Tabel 4.1.3 di bawah ini.

Tabel 4.1.3 Analisis K- tersedia di dalam tanah sawah di Desa Ranokolo

\begin{tabular}{cccc}
\hline No & $\begin{array}{c}\text { Kode } \\
\text { Sampel }\end{array}$ & $\begin{array}{c}\text { K-Tersedia } \\
(\mathbf{p p m})\end{array}$ & Kriteria \\
\hline 1 & D1C1 & 40,85 & Sedang \\
2 & D2C1 & 31,90 & Sedang \\
3 & D1I1 & 45,24 & Sedang \\
4 & D2I1 & 30,94 & Sedang \\
\hline
\end{tabular}

Berdasarkan hasil analisis Kalium (K) tersedia di dalam tanah sawah di Desa Ranokolo Kecamatan Maurole, diketahui bahwa unsure tersebut berada pada kondisi yang sedang. Unsur K merupakan unsur yang terdapat didalam tanah, dalam bentuk tersedia bagi tanaman serta dapat dimanfaatkan oleh tanaman untuk proses metabolisme. Bentuk K yang terdapat di dalam bahan induk tanah sebelum pertumbuhan tanaman dan pembentukan tanah pada umumnya sukar tersedia bagi tanaman. Nilai $\mathrm{K}$ tersedia dalam tanah diartikan sebagai $\mathrm{K}$ tanah yang dapat diekstraksi oleh air dan asam sirat.

\section{P-Total Tanah}

Unsur hara Fosfor (P) merupakan unsure haro makro yang penting bagi tanaman, terutama tanaman padi. Kandungan $\mathrm{P}$ total tanah telah dianalisis dan disajikan pada tabel 4.1.4 di bawah ini.

Tabel 4.1.4 Analisis sifat kimia P- total tanah di Desa Ranokolo Kecamatan Maurole

\begin{tabular}{llll}
\hline No & $\begin{array}{c}\text { Kode } \\
\text { Sampel }\end{array}$ & $\begin{array}{c}\text { P-total } \\
(\mathbf{m g} / \mathbf{1 0 0 g})\end{array}$ & Kriteria \\
\hline 1 & D1C1 & 120,53 & Tinggi \\
2 & D2C1 & 95,69 & Tinggi \\
3 & D1I1 & 131,15 & Tinggi \\
4 & D2I1 & 90,81 & Tinggi \\
\hline
\end{tabular}


Berdasarkan hasil analisis di Laboratorium, kandungan P-total pada tanah sawah diDesa Ranokolo berkisar antara $161,99 \mathrm{mg} / 100 \mathrm{~g}$ sampai dengan $208,39 \mathrm{mg} / 100 \mathrm{~g}$. Menurut kriteria kimia tanah, kandungan P-total tersebut tergolong dalam kriteria tinggi. Kondisi $P$ total tanah yang tinggi ini, menggambarkan bahwa kebutuhan $\mathrm{P}$ bagi tanaman padi yang ditanam di sawah tersebut tidak memerlukan input dari luar lagi. Unsur hara $\mathrm{P}$ yang ada di dalam tanah tergolong lambat pergerakannya dan umumnya hanya dapat berlangsung melalui mekanisme intersepsi akar dan difusi dalam jarak pendek. Akibatnya hanya sekitar 10-15\% fosfor yang tersedia di dalam tanah dan dapat diserap tanaman (Adiningsih, 2004).

Kandungan $\mathrm{P}$ total tanah merupakan jumlah semua komponen $\mathrm{P}$ yang ada di dalam tanah. Namum kondisi $\mathrm{P}$ total yang tinggi bukan berarti tanaman akan berkecukupan unsure tersebut. Kondisi $\mathrm{P}$ total yang tinggi dipengaruhi berbagai faktor, seperti kemampuan penyerapan dari tanaman, daya ikat unsur lain, $\mathrm{pH}$ tanah, COrganik tanah dan Fosfor yang diberikan ke tanah dalam bentuk pupuk (Hanafiah, 2010).

Kondisi tanah dengan nilai $\mathrm{P}$ yang tinggi dapat terjadi karena semakin tingginya pupuk $\mathrm{P}$ yang diberikan ke dalam tanah. Karena itu, untuk tanah sawah yang memiliki P-total dengan kategori yang tinggi, dianjurkan untuk mengurangi dosis pupuk $\mathrm{P}$. Hal ini sesuai dengan rekomdasi dari hasil penelitian yang telah dilakukan Suarjana dkk (2015) yang menyebutkan bahwa tanah dengan $\mathrm{P}$ yang tinggi, diberikan pupuk SP-36 dengan maksimal dosis 50 $\mathrm{kg} / \mathrm{ha}$.

\section{Kapasitas Tukar Kation (KTK)}

Hasil analisis Kapasitas Tukar Kation (KTK) dari sampel-sampel tanah yang di ambil di lahan padi sawah di Desa Ranokolo dapat di sajikan pada Tabel 4.1.5. Berdasarkan hasil analisis Laboratorium tanah, nilai Kapasitas Tukar Kation (KTK) pada lokasi penelitian dari sawah di Desa Ranokolo tergolong Sedang. Salah satu hal yang mempengaruhi nilai KTK tanah di lokasi penelitian di Desa Ranokolo adalah $\mathrm{pH}$ tanah. Selain $\mathrm{pH}$, Niai KTK juga dipengaruhi oleh kadar liat dan kadar bahan organik tanah Tanah yang didominasi oleh fraksi liat dan humus memiliki kapasitas pertukaran kation dan kapasitas mengikat air yang tinggi. Oleh karena itu tanah yang didominasi oleh fraksi liat dan humus memiliki stabilitas agregat yang tinggi karena adanya ikatan dalam pertikel - pertikel tanah.

Tabel 4.1.5. Hasil analisis Kapasitas Tukar Kation (KTK) di Desa Ranokolo Kecamatan Maurole

\begin{tabular}{llll}
\hline No & Kode Sampel & $\begin{array}{c}\text { KTK } \\
(\mathbf{m e} / \mathbf{1 0 0 g})\end{array}$ & Kriteria \\
\hline 1 & D1C1 & 39,13 & Sedang \\
2 & D2C1 & 37,44 & Sedang \\
3 & D1I1 & 38,45 & Sedang \\
4 & D2I1 & 36,96 & Sedang \\
\hline
\end{tabular}

Menurut Arthagama (2009) tanah yang memiliki KTK Sedang memerlukan pemupukan tanah dengan dosis tinggi, agar dapat tersedia untuk tanaman. Apabila pupuk diberikan dalam jumlah sedikit, maka unsure hara akan 
kurang tersedia bagi tanaman. Hal ini dikarenakan akan lebih banyak unsure hara yang terikat oleh tanah. Bila KTK tanah rendah pemupukan tidak boleh diberikan sekali dalam jumlah yang banyak karena mudah tercuci dan tidak efisien untuk tanaman di lahan persawahan.

\section{Kejenuhan Basa}

Hasil analisis Kejenuhan Basa (KB) dari sampel-sampel tanah yang di ambil di lahan padi sawah di Desa Ranokolo dapat di sajikan pada Tabel 4.1.6 di bawah ini.

Tabel 4.1. Hasil Analisis Kejenuhan Basa (KB) di Desa Ranokolo

\begin{tabular}{cccc} 
No & Kode Sampel & KB $(\boldsymbol{\%})$ & Kriteria \\
\hline 1 & D1C1 & 73,60 & Tinggi \\
2 & D2C1 & 80,78 & Tinggi \\
3 & D1I1 & 75,71 & Tinggi \\
4 & D2I1 & 78,87 & Tinggi \\
\hline
\end{tabular}

Berdasarkan hasil analisis Laboratorium nilai $\mathrm{KB}$ disetiap unit lahan pada lokasi penelitian di lahan sawah di Desa Ranokolo tergolong tinggi. Presentase nilai $\mathrm{KB}$ masing masing sampel lahan yaitu unit lahan D1C1 sebesar 73, 60\%, unit lahan D2C1 sebesar 80,78 \%, lahan D1I1 sebasar $75,71 \%$ dan unit lahan D2I1 sebesar $78,87 \%$.

Menurut Purwanto (2008) kejenihan basah bernilai tinggi berarti ketersediaan kation-kation basa cukup banyak untuk keperluan tanaman dari segi hara tanah. Jumlah masimum kation yang dapat diserap tanah menunjukkan besarnya nilai kapasitas tukar kation tanah tersebut. Kejenuhan basa berhubungan erat dengan $\mathrm{pH}$ tanah. Tanah dengan $\mathrm{pH}$ rendah mempunyai kejenuhan basah rendah, sedangkan tanah dengan $\mathrm{pH}$ tinggi mempunyai kejenuhan basa yang tinggi pula. Terlihat dari hasil analisis KB tanah pada nilai $\mathrm{pH}$ tanah semua unit lahan berkisar 6,5 yang tergolong netral yang menyebabkan kejenuhan basah disemua unit lahan dilokasi penelitian menjadi lebih tinggi

\section{Kriteria Kesuburan Tanah}

Kesuburan Tanah adalah kemampuan suatu tanah untuk menghasilkan produk tanaman yang diinginkan, pada lingkungan tempat tanah itu berada. Produk tanaman berupa: buah, biji, daun, bunga, umbi, getah, eksudat, akar, trubus, batang, biomassa, naungan, penampilan dan sebagainya. Tabel Kesuburan Tanah dapat dilihat pada Tabel 4.2.

Tabel 4.2. Status Kesuburan Tanah Sawah Di Desa Ranokolo Kecamatan Maurole

\begin{tabular}{ccccccc}
\hline $\begin{array}{c}\text { Kode } \\
\text { sampel }\end{array}$ & C-Organik & $\begin{array}{c}\text { K } \\
\text { Tersedia } \\
(\mathbf{p p m})\end{array}$ & $\begin{array}{c}\mathbf{P} \text { Total } \\
(\mathbf{m g} / \mathbf{1 0 0 g})\end{array}$ & $\begin{array}{l}\text { KTK } \\
(\mathbf{m l} / \mathbf{1 0 0 g})\end{array}$ & $\begin{array}{c}\text { KB } \\
(\boldsymbol{\%})\end{array}$ & $\begin{array}{c}\text { Status } \\
\text { Kesuburan }\end{array}$ \\
\hline D1C1 & $1,98 \mathrm{R}$ & $40,85 \mathrm{~S}$ & $120,53 \mathrm{~T}$ & $39,13 \mathrm{~S}$ & $73,60 \mathrm{~T}$ & Rendah \\
D2C1 & $1,57 \mathrm{R}$ & $31,90 \mathrm{~S}$ & $95,69 \mathrm{~T}$ & $37,44 \mathrm{~S}$ & $80,78 \mathrm{~T}$ & Rendah \\
D1I1 & $2,08 \mathrm{~S}$ & $45,24 \mathrm{~S}$ & $131,15 \mathrm{~T}$ & $38,45 \mathrm{~S}$ & $75,71 \mathrm{~T}$ & Rendah \\
D2I1 & $1,55 \mathrm{R}$ & $30,94 \mathrm{~S}$ & $90,81 \mathrm{~T}$ & $36,96 \mathrm{~S}$ & $78,87 \mathrm{~T}$ & Rendah \\
\hline
\end{tabular}


Dari hasil analisis kesuburan tanah, diketahui bahwa semua lokasi budidaya padi varietas Ciherang dan IR di Desa Ranokolo tergolong berstatus kesuburan rendah. Hal ini dapat dipengaruhi oleh Kadar C-organik Tanah di sawah-sawah tersebut. Hasil analisis kadar C organik pada lokasi penelitian didominasi oleh kondisi rendah. Menurut penelitian yang dilakukan oleh Musthofa (2007) bahwa kandungan bahan organik harus dipertahankan tidak kurang dari $2 \%$. Jika dilihat kandungan $\mathrm{C}$ organik pada setiap jenis tanah di lahan persawahan menujukkan rata-rata $<2 \%$ masih tergolong rendah. Hal inilah yang menjadi penyebab rendahnya kesuburan tanah. Kandungan $\mathrm{C}$ organik rendah secara tidak langsung menunjukkan rendahnya produksi bahan organik pada tanah penelitian, karena bahan organik tanah merupakan salah satu parameter yang menetukan kesuburan tanah.

Kandungan C-organik dalam tanah merupakan hasil dari pelapukan sisa sisa tanaman atau binatang yang bercampur dengan bahan mineral lain didalam tanah pada lapisan atas tanah, yang mempunyai fungsi yaitu Fisika, kimia dan biologi tanah (Hanafiah, 2010). Fungsi C-Organik terkait sifat Fisik tanah adalah memperbaiki struktur tanah, memperbaiki aerasi tanah, meningkatkan daya penyangga air tanah, menekan laju erosi. Fungsinya terkait sifat kimia tanah adalah menyangga dan menyediakan hara tanaman, meningkatkan efisiensi pemupukan, menetralkan sifat racun Al dan Fe. Dan fungsinya terkait biologi tanah adalah sumber energi bagi jasad renik atau microba tanah yang mampu melepaskan hara bagi tanaman.

\section{KESIMPULAN}

Kesimpulan yang dapat diambil dari penelitian ini adalah:
1. Kriteria kimia tanah sawah di Desa Ranokolo Kecamatan Maurole adalah sebagai berikut, variable C-Organik di Desa Ranokolo Kecamatan Maurole tergolong rendah, $\mathrm{K}$ tersedia tergolong sedang, P-total tergolong tinggi, KTK sedang dan Kejenuhan Basa tergolong sedang.

2. Dari hasil analisis kesuburan tanah, maka Kriteria kesuburan tanah sawah di Desa Ranokolo Kecamatan Maurole Kabupaten Ende adalah rendah dengan faktor pembatas C-Organik.

\section{UCAPAN TERIMA KASIH}

Pada kesempatan ini penulis ingin mengucapkan terima kasih kepada semua pihak yang telah membantu dengan caranya masing-masing dalam melengkapi tulisan ini

\section{DAFTAR PUSTAKA}

Adiningsih, S. 2004. Dinamika Hara Dalam Tanah Danmekanisme Serapan Hara. Pusat Penelitian Tanah. Kementrian Pertanian, Jakarta.

Anna R, dkk. 2010. Petunjuk ppraktikum mikro biologi edisi revisi 5 . Yogyakarta: FMIPA

Arthagama, I. D. M. 2009. Evaluasi Kesuburan Lahan Tanah Pertanaman Jeruk Di Desa Les Kecamatan Tejakula Berdasarkan Uji Tanah. Jurusan Ilmu Tanah, Fakultas Pertanian, 
UNUD. Jurnal Agritrop Vol. 28, No.1. Hal.15-21.

Barus, T. et al, 2014. Penuntun Praktikum Kimia Bahan Alam Hayati. Depertemen Kimia FMIPA Unifersitas Sumatra Utara. Medan

Hanafiah K A. 2010. Dasar- Dasar Ilmu Tanah. Jakarta: PT. Raja Grafindo Persada.

Kartasapoetra, A. G. 1989. Kerusakan Tanah Pertanian. Bina Aksara Jakarta.

PPT. 1995.Kombinasi Beberapa Sifat Kimia Tanah dan Status Kesuburanya. Bogor.

Purwanto, E. 2008.Kajian Macam Media Tanam Dan Konsentasi Iba Terhadap Pertumbuhan Stek Jarak Pagar (Jatropha Curcas I). Program studi agronomi. Universitas Sebelas Maret.
Rahayu, 2008. Studi Analisis Kualitas Tanah Pada Beberapa Penggunaan Lahan Dan Hubungannya Dengan Tingkat Erosi Di Sub Das Keduang Kecamatan Jatisrono Wonogiri.Tesis.

Sulakhudin.,Susanti D.,Gafur S. 2017. Kajian Status Kesuburan Tanah Pada Tanah Sawah di Kecamatan Sungai Kunyit Kabupaten Menpawah.Jurnal Pedon Tropika. Vol. 3 (1): 106114.

Susanto, Rachman. 2002. Pertanian Organik, Menuju Pertanian Alternatif dan Berkelanjutan.Penerbit Kanisius : Yogyakarta.

Susilawati. 2008. Karateristik Sifat Fisik dan Kimia Ubikayu. Jurnal Teknologi Industri Dan Hasil Pertanian.13(2):04-13. 